\title{
Archaeobotany of Sos Höyük, northeast Turkey
}

\author{
Catherine Longford ${ }^{1}$ \\ Andrew Drinnan² \\ Antonio Sagona
}

\author{
'Department of Archaeology \\ The University of Sheffield \\ S1 4ET, UK \\ c.longford@sheffield.ac.uk
${ }^{2} S c h o o l$ of Botany
The University of Melbourne
3010 Australia

${ }^{3}$ School of Historical Studies, Centre for Classics and Archaeology The University of Melbourne

3010 Australia

\section{Abstract}

Sos Höyük, located in the Pasinler Valley of northeast Turkey, is a multiperiod site occupied from the Late Chalcolithic to the Medieval Period. No major archaeobotanical analysis has been conducted on the carbonised plant remains from Sos Höyük. Samples from three time periods, the Late Chalcolithic, Middle Bronze and Iron Age were selected for analysis. Examination of both seeds and wood charcoals has indicated a complex and changing pattern of plant use over time. From wood charcoals, four vegetation zones (riparian woodland, open oak woodland, mountain pine forest and birch forest) were identified in the Pasinler Valley during antiquity and exploited by the occupants of Sos Höyük. Change in wood pro curement patterns suggests the depletion of the open oak woodland in the Pasinler Valley between the Middle Bronze Age and Iron Age. A reduction in wood resources is supported by the use of dung fuel as a firewood supplement from the Middle Bronze Age. These findings correlate with the pattern of deforestation across the Near East and suggest a combination of human and environmental causes for vegetation change in the Bronze Age. A second deforestation event is proposed for the modern period.

Keywords: Vegetation history; deforestation; climate change; archaeobotany; Turkey 


\section{Introduction}

Sos Höyük is an archaeological site located in the modern village of Yiğittaşı in Erzurum Province, northe ast Turkey (Figure 1). The site is situated at an altitude of $1800 \mathrm{~m}$ in the narrow Pasinler Valley flanked by the Karapazarı Mountains to the north and the Palandöken Range to the south, both of which reach eleva tions in excess of $3000 \mathrm{~m}$. As is the case today, in antiquity the Pasinler Valley lay on one of the main routes through the mountains of Eastern Anatolia linking Western Turkey to Iran and the Caucasus. Members of the University of Melbourne's Northeastern Anatolia project, led by Antonio and Claudia Sagona, excavated the mound of Sos Höyük from 1994 to 2000 (see Sagona et al. 1995, 1996, 1997, 1998; Sa gona and Sagona 2000. Study seasons, accompanied by a field survey of the surrounding region, were conducted from 2001 to 2003.

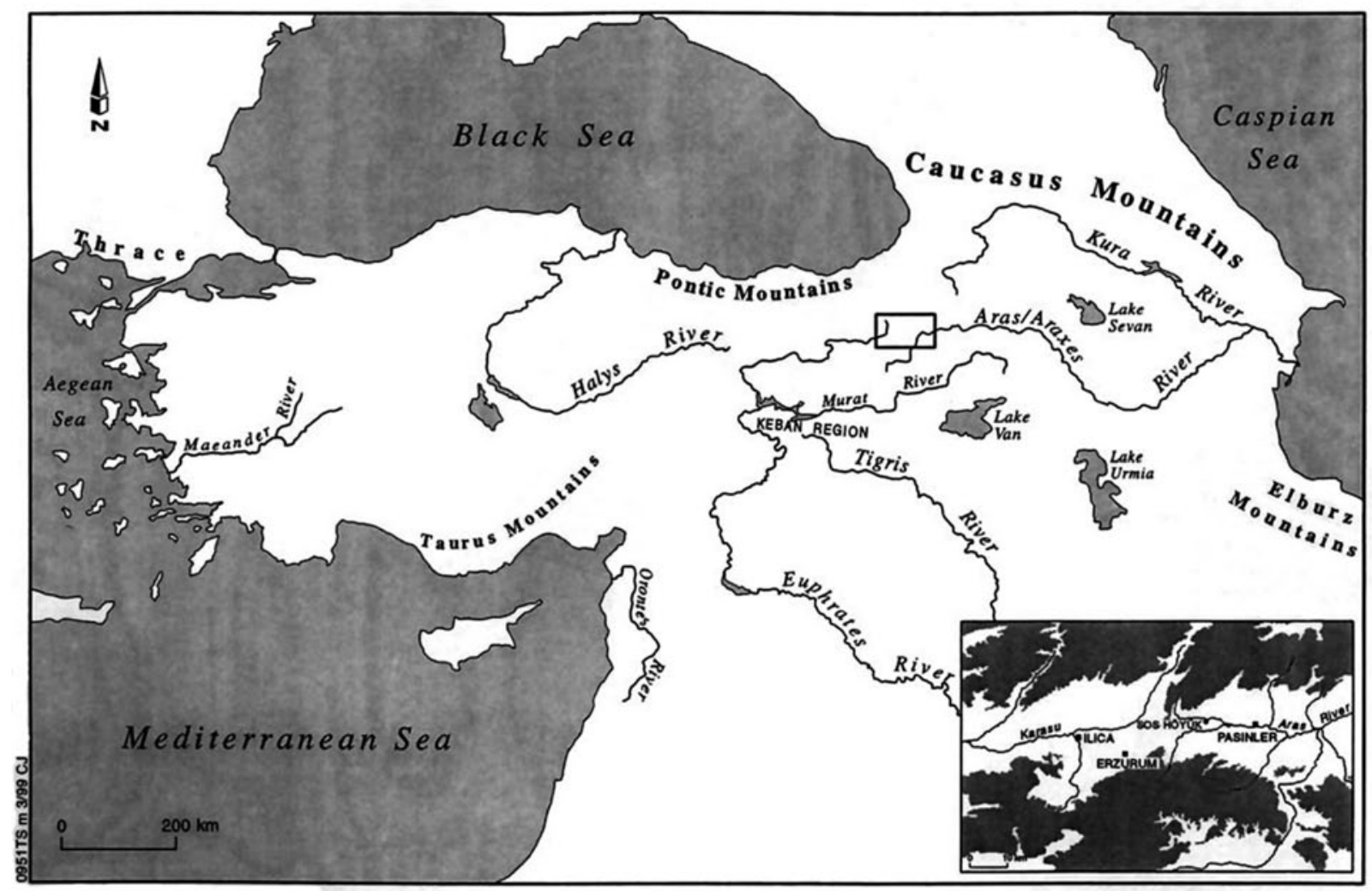

Figure 1. Map of Ancient Anatolia, Transcaucasia, and Northwest Iran showing the location of Sos Höyük (Sagona 2000)

Excavations at the site have revealed that Sos Höyük was initially used in the Late Chalcolithic (late 4th millennium BC) by agro-pastoralists who were part of the Early Transcaucasian (or KuraAraxes) cultural complex. Communities of this tradition continued to occupy Sos Höyük throughout the greater part of the Bronze Age. Judging from architectural remains and analysis of some of the faunal data, these early villagers incorporated a degree of transhumance into their lifestyle, though the exact nature of this economic activity and how it related to sedentary agricultural practices has yet to be determined. During the late second millennium BC (Late Bronze Age) occupation appears to have been seasonal, though this may reflect the limited area of this period that was excavated; more permanent buildings may still lie unexcavated at the southern end of the mound. In the Iron Age, the site was home to a farming community on the edge of the Urartian Empire and later within the 18th Satrapy of the Persian Empire. The Iron Age plant remains are characterised by an excellent level of preservation with carbonised rush matting, basketry, rope, furniture and a pair of charred sandals recovered from a burnt 
house. Sos Höyük was abandoned in the second century BC and reoccupied briefly after the Seljuk conquest of Anatolia in the eleventh century $\mathrm{AD}$ before the present village was established some time within the modern era (Table 1) (Sagona and Sagona 2000).

\begin{tabular}{|ll|}
\hline Period & Date \\
\hline Late Chalcolithic & $3500-3000$ BC \\
\hline Bronze Age & \\
Early Bronze Age & $3000-2200$ BC \\
Middle Bronze Age & $2200-1500$ BC \\
Late Bronze Age & $1500-1000$ BC \\
\hline Iron Age & $1000-300$ BC \\
\hline Post-Achaemenid & $300-200$ BC \\
\hline Medieval & $1100-1300$ AD \\
\hline
\end{tabular}

Table 1. Sos Höyük chronology (Sagona 2000).

Post-excavation research at Sos Höyük has included zooarchaeology (Howell-Muers, 2001), ethnoarchaeology (Hopkins 2000), osteoarchaeology (Parr et al. 1999) and palynology (Connor n.d.). While wood charcoal is plentiful throughout the sequence, little analysis, other than radiocarbon dating, has so far been undertaken on these samples. As part a broad environmental study of the Bronze Age at Sos Höyük, Newton (2004) performed a limited study on the wood charcoal remains, recommending that further intensive analysis be performed. The closest archaeobotanical studies to Sos Höyük have been conducted beyond the southern Palandoken Mountains in south-eastern Anatolia at Arslantepe (Frangipane et al. 2001), Aşvan (Willcox 1974) and Kurban Höyük (Miller 1986) and to the east at Patnos (Dönmez 2003). No archaeobotanical analysis has been completed in northeast Anatolia.

In the Near East most archaeobotanical work has focused on the early domestication of crop plants in the Neolithic and relatively little research has been undertaken into the plant based subsistence economy of the Chalcolithic, Bronze and Iron Ages (Miller 1991, Reihl and Nesbitt 2003). Analysis of the plant remains from Sos Höyük would help to fill this void by providing information on subsistence in Eastern Turkey from the Late Chalcolithic to Medieval Period. Sos Höyük is located in the Eastern Highlands of Anatolia and provides a rare opportunity to investigate the subsistence strategies of a mountain village in comparison to the lowland settlements already documented to the south and west of the Palandöken Range.

Similarly, Sos Höyük is ideally placed to examine the vegetation history of a mountain zone. Tod ay the Pasinler Valley is practically treeless, dominated by alpine wildflowers with riparian trees restricted to riverbanks, and pollarded poplars along roadsides and around villages. The surrounding mountains are devoid of trees except in steep gullies near the plateau of the Karapazarı range where isola ted pockets of birches (Betula sp.) pines (Pinus sylvestris) and stunted oaks (Quercus macranthera) remain (Newton 2004; personal observation). In contrast to the current treeless steppe, Xenophon, writing of his retreat through the Pasinler Valley from Persia to the Black Sea in the fourth century BC, recorded 'wood in abundance' in the Erzurum region (Xenophon IV.5.2, Sagona 2004). Thus, in ancient times, the Pasinler Valley and nearby mountain ranges were likely to have been wooded. A pollen core from Bulemaç, south east of Sos Höyük on the Pasinler Plain, suggests that the area was dominated by a Pinus woodland for $\mathrm{m}$ ost of the Holocene (Collins et al. 2005). Prehistoric deforestation has been identified via wood charcoal analysis across southwest Asia (Willcox 1974, Miller 1985). The present vegetation mosaic of isolated trees amid herbaceous steppe found across Central and Eastern Turkey is thought to have resulted from deforestation in antiquity (McNeill 1992, Woldring and Cappers 2001). 
The research described here was a pilot study that aimed to bring a highland perspective to archaeobotanical research in the Near East and begin much needed work in northeast Anatolia. In particular, the project aimed to study material from the Late Chalcolithic, Middle Bronze and Iron Ages to reconstruct the vegetation history of the Pasinler Valley and relate this to environmental change across the Near East. Here we present the preliminary findings of the study, concentrating primarily on the ecological changes in the Pasinler Valley during that period.

\section{Method}

Samples for archaeobotanical analysis were taken from recognised floor levels rich in organic material (up to $10 \mathrm{~cm}$ above the floor), but not from the mixed fill between layers. A minimum of 60 litres of soil was collected randomly from the floor level of each targeted excavation locus, with hearths preferentially sampled. The soil was processed by bucket flotation to collect the charred plant remains, with the heavy residue wet sieved and manually sorted to collect non-floating organic remains. After being air dried in cloth bags the material was stored in Yiğittası until 2003 when it was transported to Australia for labora tory analysis.

After initial examination, three loci were selected for analysis based on the amount of carbonised material and period of deposition. The Late Chalcolithic sample was from the surface of a burnt plaster floor of a Transcaucasian roundhouse dated to 3100-2600 cal BC (Beta-135363, calibrated using OxCal v3.10). The Middle Bronze Age (2580-2340 cal BC (OZF943)) sample was from a secondary deposit in a plastered rubbish pit. The Iron Age remains were from the destruction debris of a burnt house from 1260$890 \mathrm{cal}$ BC (Beta-95214). Detailed explanation of each context is found in Sagona and Sagona (2000). Each sample was sieved into three fractions: $>2 \mathrm{~mm},>0.5 \mathrm{~mm}$ and $<0.5 \mathrm{~mm}$, as suggested by Pearsall (2000).

For seed analysis, whole seeds and seed fragments were collected from the $>2 \mathrm{~mm}$ sample fractions and only whole seeds from the $>0.5 \mathrm{~mm}$ portion, following Miller (1998). These were identified using an Olympus SZ60 stereomicroscope with the aid of illustrative archaeobotanical texts by van Zeist and Bakker-Heeres (1985, 1986), Zohary and Hopf (2000), and seed atlases (Berggren 1969, 1981; Anderberg 1994). Cereal grain identification was assisted by reference to modern seed samples of wild and domesticated cereals sent from the Australian Winter Cereal Collection in Tamworth. Where possible, taxa were identified to species level, otherwise to genus. Nomenclature follows Zohary and Hopf (2000) for cultivated species and for wild taxa follows the Flora of Turkey by Davis (1965-1985).

Wood charcoal fragments were sorted from the $>2 \mathrm{~mm}$ sample fractions. For this preliminary study an initial subsample size of 50 charcoal pieces per sample was selected as a compromise between the five of Miller (2004) and 200 of Asouti and Hather (2001). To check the appropriateness of examining 50 pieces per unit studied, a variant of Smart and Hoffman's (1988) taxon-number curve was used. In each instance the taxon number curve plateaued prior to identification of all 50 fragments, indicating that a 50 fragment count provided an adequate sub-sample. The 50 charcoal fragments were randomly selected for examination under an Olympus SZH stereomicroscope. Each piece was cut with a razor blade to expose the transverse, tangential longitudinal and radial longitudinal planes. The wood was identified using keys for European and Near Eastern wood (Greguss 1955; Brazier and Franklin 1961; Fahn et al. 1986; Schoch et al. 2004) and through reference to a modern comparative collection created as part of this research. Fragments that could not be identified under the stereomicroscope were identified under the Phillips XL30 Field Emission Scanning Electron Microscope (FESEM), in the School of Botany at the University of Melbourne. Confirmation of identifications made under the stereomicroscope was conducted by randomly selecting a charcoal piece from each taxon group identified, for FESEM examination and photographing as a quality control. Nomenclature follows the Flora of Turkey (Davis 1965-1985). Identifications were made to genus or, if possible, to species. For Salicaceae, identification was made to family level since, by wood anatomy, the two genera Salix and Populus are indistinguishable except at high magnification (Schoch et al. 2004). With the majority of identifications made with the stereomicroscope, Salix and Populus could not be differentiated and were recorded at the family level. 


\section{Results}

\section{Seeds}

A summary of seed abundance data for the Late Chalcolithic, Middle Bronze and Iron Age levels is presented in Table 2. In the Late Chalcolithic sample, only wheat (Triticum sp.) and barley (Hordeum vulgare) grains were identified with naked wheats (Triticum aestivum ssp. vulgare/T. turgidum ssp. durum) being most abundant. The recovery of a T. aestivum ssp. vulgare rachis indicates hexaploid bread wheat may have been present. A greater variety of plant taxa were discovered in the Middle Bronze Age pit. Wheat and barley were found with hulled barley (Hordeum vulgare) the most common taxa. A diverse wild seed flora with Galium sp., Asperula sp., Polygonum sp., Lolium sp, and members of the Boraginaceae, Caryophylaceae, Convolvulaceae, Fabaceae and Poaceae families were present. Remains of sheep/goat dung were also found. In the Iron Age sample, naked wheat was the most dominant grain type, with seeds of millet (Setaria italica), grape (Vitis vinifera), lentil (Lens culinaris), and five wild taxa also found.

$\begin{array}{lcl}\text { Taxon (English name) } & \text { Plant Part } & \text { Period } \\ & \text { Late } & \text { Middle Bronze } \\ \text { Chalcolithic } & \text { Age } & \text { Iron Age }\end{array}$

\section{Crops}

Triticum aestivum L. ssp. vulgare /T.

\begin{tabular}{|c|c|c|c|c|}
\hline turgidum L. conv. durum (bread/durum wheat) & grain & 84 & 16 & 715 \\
\hline Triticum sp. (wheat) & grain & 35 & 4 & 71 \\
\hline Triticum aestivum ssp. vulgare (bread wheat) & rachis & 2 & - & - \\
\hline Hordeum vulgare L. (hulled barley) & grain & 46 & 175 & 14 \\
\hline H. vulgare L var. nudum (naked 6-row barley) & grain & - & 1 & - \\
\hline Cerealia (cereal) & grain frags. & - & - & 1 \\
\hline Setaria italica L. P. Beauv. (foxtail millet) & grain & & & \\
\hline Lens culinaris L. (lentil) & seed & - & - & 1 \\
\hline Vitis vinifera L. (grape) & seed & - & - & 1 \\
\hline
\end{tabular}

Wild plants

\begin{tabular}{|c|c|c|c|c|}
\hline Galium L. sp. & seed & - & 2 & 2 \\
\hline Asperula L. sp. & seed & - & 1 & 1 \\
\hline Polygonum L. sp. & seed & - & 3 & - \\
\hline Lolium L. sp. & seed & - & 1 & 2 \\
\hline Ranunculus arvensis L. & seed & - & - & 1 \\
\hline Boraginaceae & seed & - & 1 & - \\
\hline Caryophylaceae & seed & - & 1 & - \\
\hline Convolvulaceae & seed & & 1 & \\
\hline Fabaceae & seed & - & 7 & 2 \\
\hline Poaceae & seed & 4 & 2 & - \\
\hline Unidentified & seed & - & 3 & 6 \\
\hline Pinus sp. cone & cone & - & - & 1 \\
\hline
\end{tabular}

Other

Sheep/goat faecal pellets

Table 2. Summary of seed and chaff data for Sos Höyük for the Late Chalcolithic, Middle Bronze and Iron Age levels examined. Data is recorded as sum individual seeds/units with weight $(\mathrm{g})$ recorded for Cerealia fragments. Nomenclature follows the modern system described in Zohary and Hopf (2000) for cereal taxa and the Flora of Turkey (Davis 1965-1985) for wild taxa. 
These preliminary findings from Sos Höyük are an interesting contrast to the rest of the Near East where hulled wheats (emmer and einkorn) are known to have decreased in dominance over the Bronze Age with naked and free-threshing wheats becoming the main cereal crops by the Iron Age (Zohary and Hopf 2000). In Eastern Turkey this transition is thought to have occurred in the Early Bronze Age (Riehl and Nesbitt 2003). Preliminary results from Sos Höyük, showing the prevalence of naked wheat from the earliest period studied may indicate that the shift from hulled wheat to naked wheat may have occurred earlier in the northeastern highlands of Anatolia than in the rest of the region. This could be because this region in the Late Chalcolithic was part of the Early Transcaucasian cultural complex. Genetic evidence suggests bread wheat was first domesticated on the southern flanks of the Caucasus (Dvorak et al. 1998), and in many settlements from the Neolithic onwards it is the most dominant wheat type identified (Wasylikowa et al. 1991). The presence of bread wheat rachis segments and quantity of naked wheat in the Late Chalcolithic may be because T. aestivum ssp. vulgare was the main wheat of the Early Transcaucasian crop assemblage.

\section{Wood}

Seven taxa were identified in the wood charcoal assemblages (Table 3, Figure 2). In the Late Chalcolithic Pinus cf. sylvestris (Scots Pine), Quercus sp.(oak) and Salicaceae (willow/poplar) were found with Salicaceae being the most common taxa present. P. cf. sylvestris was the most abundant taxon in a more diverse assemblage from the Middle Bronze Age pit, which also contained Betula sp. (birch), Quercus sp., Ulmus sp. (elm), Acer sp. (maple) and Salicaceae. In the Iron Age P. cf. sylvestris, Salicaceae, Betula sp. and Lonicera sp. (honeysuckle) were identified with the riverine Salicaceae being the most dominant charcoal type.

\begin{tabular}{|c|c|c|c|c|c|c|}
\hline \multirow{3}{*}{$\begin{array}{l}\text { Period } \\
\text { Sample numbers } \\
\text { Taxon }\end{array}$} & \multirow{2}{*}{\multicolumn{2}{|c|}{$\begin{array}{l}\text { Late Chalcolithic } \\
\text { L17b } 4299142\end{array}$}} & \multirow{2}{*}{\multicolumn{2}{|c|}{$\begin{array}{l}\text { Middle Bronze Age } \\
\text { L16c } 403560\end{array}$}} & \multirow{2}{*}{\multicolumn{2}{|c|}{$\begin{array}{l}\text { Iron Age } \\
\text { J14 } 1299122\end{array}$}} \\
\hline & & & & & & \\
\hline & Count & $\%$ & Count & $\%$ & Count & $\%$ \\
\hline Pinus cf. sylvestris L. & 10 & 20 & 21 & 42 & 17 & 34 \\
\hline Salicaceae & 38 & 76 & 9 & 18 & 19 & 38 \\
\hline Betula sp. & - & - & 1 & 2 & 9 & 18 \\
\hline Lonicera sp. & - & - & - & - & 1 & 2 \\
\hline Quercus sp. & 2 & 4 & 12 & 24 & - & - \\
\hline Ulmus sp. & - & - & 1 & 2 & - & - \\
\hline Acer sp. & - & - & 3 & 6 & - & - \\
\hline Indeterminate & - & - & 3 & 6 & 4 & 8 \\
\hline Total & 50 & 100 & 50 & 100 & 50 & 100 \\
\hline
\end{tabular}

Table 3. List of the taxa present in the wood charcoal assemblage from Sos Höyük in the Late Chalcolithic, Middle Bronze and Iron Age samples, recorded as absolute fragment counts (Count) and relative percentages (\%).

\section{The Environmental History of Sos Höyük}

While this study is based on only a small number of samples, the preliminary archaeobotanical record from Sos Höyük preserves a diverse charcoal flora for the Pasinler Valley. Although very few trees are pre sent in the vicinity of Sos Höyük today, mainly along roadsides, rivers and near villages, the past enviro nment can be inferred based on the species' modern habitat preferences as recorded in Zohary (1973), 

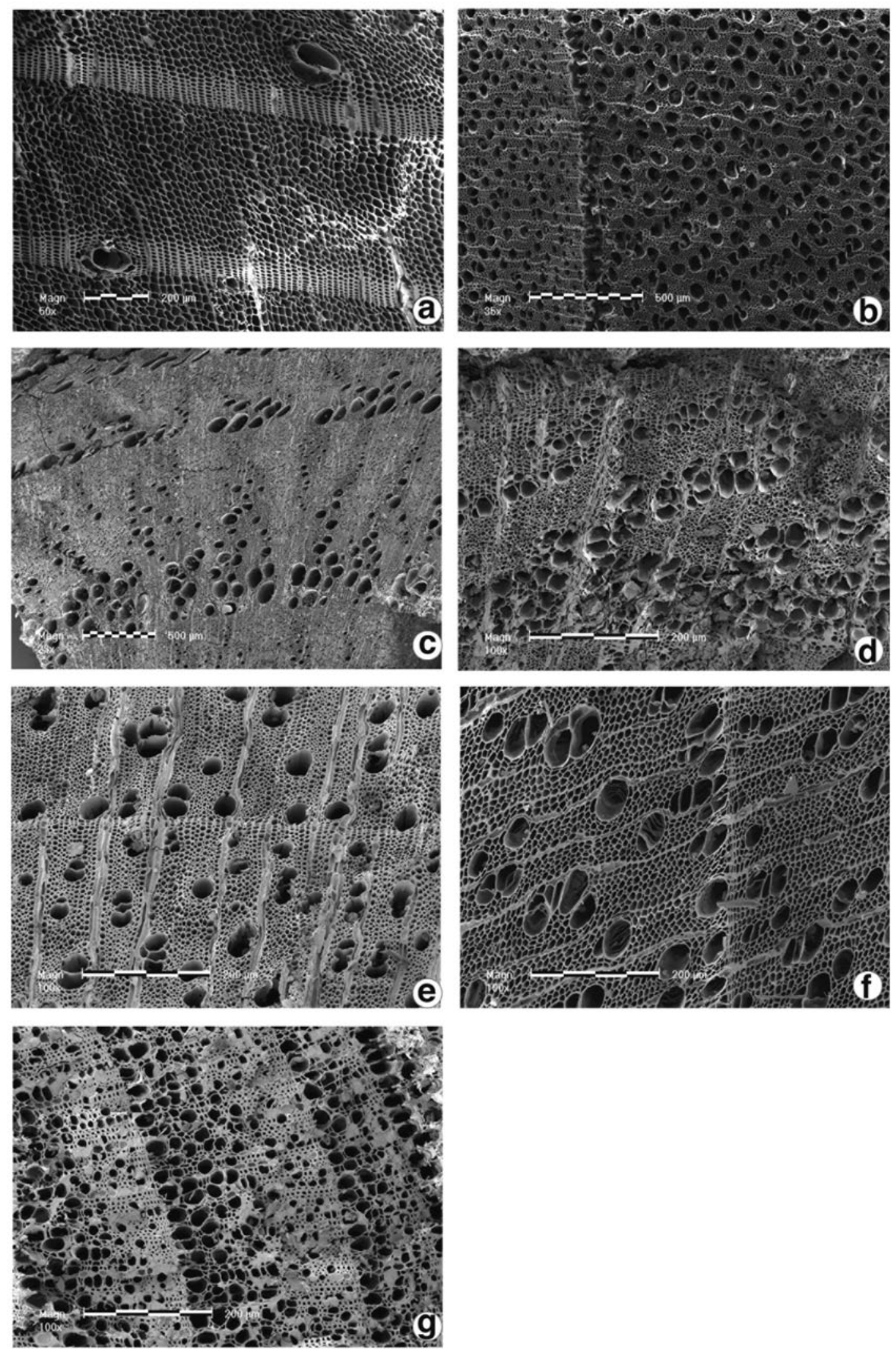

Figure 2. Representative transverse sections of taxa identified in the wood charcoals studied from Sos Höyük photographed under the FESEM. Scale bars are in increments of 50 um. a) Pinus (f. sylvestris; b) Salicaceae; c) Quercus sp.; d) Ulmus sp.; e) Acer sp.; f) Betula sp.; g) Lonicera sp. 
Fairbairn et al. (2002), Newton (2004) and Davis (1965-1985). When integrated, the charcoal taxa form five vegetation types that have distinct distributions in the site's locale (Table 4, Figure 3). The environmental reconstruction (Figure 3) incorporates the northern half of the Pasinler Valley, in which Sos Höyük is located, and the Karapazarı Mountains, since the Aras River to the south of the site forms a socio-geographical boundary in the Valley which may have marked the edge of village territory in ancient times (Sagona 2004). Along the rivers and alluvial flats, riparian woodlands dominated by willows and poplars were probably present. Disturbed land, including cultivated fields near villages and the village itself would have been home to wild and weedy annuals and perennials. On the Pasinler Plain, the severe winter frosts and winds depress the tree line, limiting tree growth to scattered stands (Stern 1983). This Bronze Age steppe savannah was probably an open oak-dominated woodland with maple, elm, almond, and shrubby Rosaceae, and juniper as is still present in some parts of Anatolia. The oak woodland would have spread across the wild subalpine flower-covered valley and into the foothills. Further into the Karpazarı Range, the open oak woodland would have graded into the Pinus sylvestris forest that may have had an oak and maple understorey at lower altitudes. At the upper tree line beneath the Karapazarı plateau, birch would have grown, particularly dense in sheltered north-facing niches, together with stunted pines, Rhododendron and juniper as is found in Northern Turkey today (Connor pers. comm.). This reconstruction matches the habitat requirements of wild animals found at Sos Höyük in the Early Bronze Age with brown bears in coniferous forests, wild sheep in the wooded mountains, red deer in woodlands and golden eagles preferring the open plain with scattered trees (Howell-Meurs 2001; Newton 2004; Sagona et al. 1997).

\begin{tabular}{|c|c|c|c|}
\hline Location & Vegetation type & $\begin{array}{l}\text { Taxa identified in } \\
\text { assemblage }\end{array}$ & $\begin{array}{l}\text { Possible taxa in } \\
\text { association }\end{array}$ \\
\hline $\begin{array}{l}\text { river banks/alluvial } \\
\text { flats }\end{array}$ & riparian & $\begin{array}{l}\text { willow, poplar } \\
\text { (Salicaceae), elm } \\
\text { (Ulmus), Polygonum }\end{array}$ & $\begin{array}{l}\text { ash (Fraxinus) alder } \\
\text { (Alnus), Carex, Juncus, }\end{array}$ \\
\hline plain & disturbed land & $\begin{array}{l}\text { Ranunculus, Galium, } \\
\text { Lolium, Asperula, } \\
\text { Triticum, Hordeum, } \\
\text { Lens, Cucumis, } \\
\text { Convolvulaceae }\end{array}$ & $\begin{array}{l}\text { Bromus, Phalaris, } \\
\text { Rumex, Trifolium }\end{array}$ \\
\hline plain and foothills & $\begin{array}{l}\text { oak steppe- } \\
\text { woodland }\end{array}$ & $\begin{array}{l}\text { oak (Quercus), } \\
\text { maple (Acer), } \\
\text { honeysuckle (Lonicera), } \\
\text { elm (Ulmus) }\end{array}$ & $\begin{array}{l}\text { hawthorn (Crataegus), } \\
\text { pears (Pyrus) } \\
\text { cherry (Prunus), } \\
\text { terebinth (Pistachia) } \\
\text { juniper (Juniperus), } \\
\text { rose (Rosa) } \\
\text { almond (Amygdalus) }\end{array}$ \\
\hline $\begin{array}{l}\text { lower mountain } \\
\text { slope }\end{array}$ & pine forest & $\begin{array}{l}\text { pine (Pinus sylvestris), } \\
\text { honeysuckle (Lonicera), } \\
\text { maple (Acer), oak (Quercus), }\end{array}$ & juniper (Juniperus) \\
\hline
\end{tabular}

Table 4. Summary of vegetation reconstruction for the Pasinler Valley, recording vegetation type, the taxa identified in the charcoal assemblage and the possible taxa in association for habitat location. Reconstruction based on plant ecological preferences (from data in Zohary 1973, Fairbairn et al. 2002, Newton 2004 and Davis 1965-1985). 


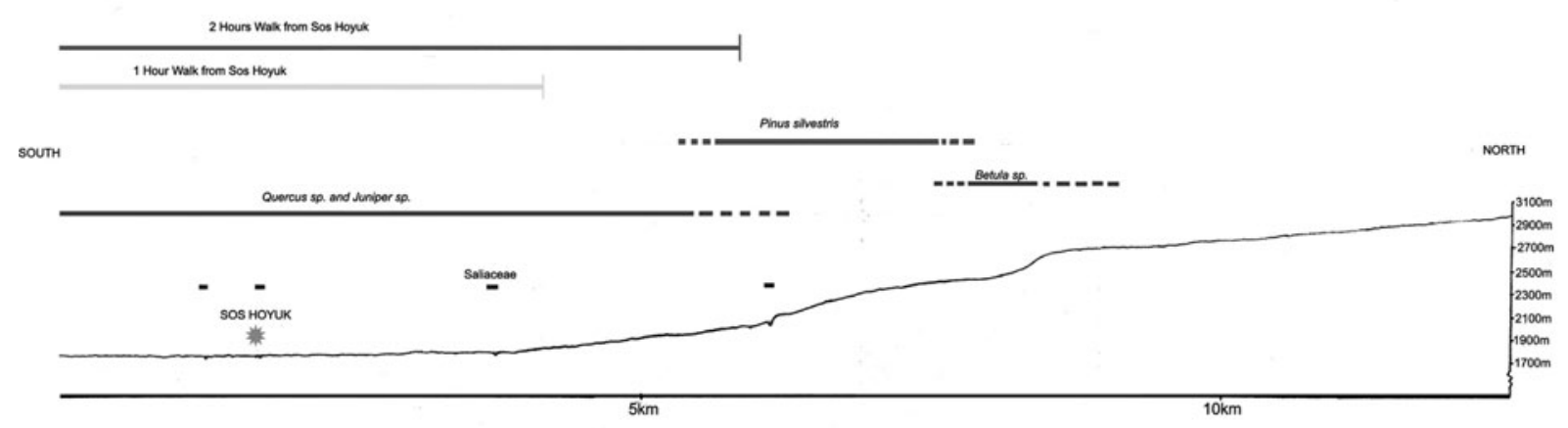

Figure 3. Possible distribution across the northern Pasinler Valley into the Karapazarı mountain range of the four vegetation types identified in charcoal from Sos Höyük. Riparian woodland along the rivers and in moist places, open oak woodland on the valley plain and into the foothills, mountain pine on the slopes of the Karapazarı mountains and birch forest at the upper treeline. Elevation and walking distance from Sos Höyük derived from topographical maps of Newton (2004).

All the wood charcoal fragments identified are elements of the Euro-Siberian Euxine phytogeographical province (Davis 1965-1985). This is in accordance with Zohary (1973) and Davis (1965) who view the East Anatolian Highlands as being a mix of relict Euro-Siberian forests and IranoTuranian steppe. As the Euro-Siberian forests were depleted over time, the Irano-Turanian steppe and shrubbery became the dominant vegetation type present in the region today. In comparison to Collins et al. (2005), this model suggests a more complex vegetation history for the Pasinler Valley with several different ecotypes present together with the Pinus woodland identified in the Bulemaç pollen core.

\section{Resource Depletion}

The depletion of the Euro-Siberian woodland is visible in the charcoal assemblage examined from Sos $\mathrm{H}$ öyük when tabulated in terms of vegetation types used over time (Table 5). From the burnt plaster floor of the Late Chalcolithic round house, Salicaceae, pine and oak were found, with Salicaceae charcoal constituting the majority of the sample. This room had a portable hearth in the form of a twinhorned andiron and is part of a succession of plaster floor levels suggesting that the occupation at this time was transient, by semi-nomadic agro-pastoralists (Sagona and Sagona 2000). Wood gathering appears to have occurred in the riparian woodland along the river close to the site with some collection of oak and pine extending wood procurement into the foothills. This use of poor-burning Salicaceae wood matches the predictive model of nomadic pastoralist behaviour proposed by Asouti and Austin (2005), in which wood selection is driven more by the proximity and quantity of fuel required for mass milk processing than the calorific quality, and hence burning properties, of the wood itself.

\begin{tabular}{llll}
\hline Vegetation Type & Late Chalcolithic & Middle Bronze Age & Iron Age \\
\hline riparian woodland & $\mathrm{xxx}$ & $\mathrm{xx}$ & $\mathrm{xxx}$ \\
\hline open oak woodland & $\mathrm{x}$ & $\mathrm{xxx}$ & $\mathrm{xxx}$ \\
\hline pine forest & $\mathrm{xx}$ & $\mathrm{xxx}$ & $\mathrm{xx}$ \\
\hline birch forest & & $\mathrm{x}$ & \\
\hline
\end{tabular}

Table 5. Summary of vegetation zones exploited in the Late Chalcolithic, Middle Bronze and Iron Age. Zone composition detailed in Table 4. $x$ = minor exploitation. $x x=$ some exploitation. $x x x=$ heavy exploitation. Intensity of use based on proportion of wood charcoal from each zone in Table 3. 
In the Middle Bronze Age pit, a greater diversity of charcoal taxa is present from all four recognised arboreal associations. More species from the plain, including maple and elm, and from the mountain slopes, birch, are found in the sample, indicating exploitation of vegetation communities beyond the settlement periphery, perhaps due to depletion of the riparian arboreal flora. This matches findings from Neolithic Çatalhöyük where most wood in the early phase of settlement was gathered from the local wetlands. Over time the resource base was broadened to include more ecological niches, including intensive harvesting in the foothills $10 \mathrm{~km}$ to the south, which at Sos Höyük seems to have occurred by the Middle Bronze Age (Fairbairn et al. 2002).

Charcoal from the Iron Age house includes taxa from the riparian woodland and mountain forests, but lacks taxa from the open oak woodland. While honeysuckle is present, its use as an ornamental in some Anatolian villages impinges on its reliability as a woodland indicator (Ertuğ 2000). This scarcity of fragments from the steppe woodland, particularly the lack of oak, may be an artificial product of sampling but could equally represent the decline of the open oak stands. Asouti and Austin (2005) also suggest that the function of different archaeological contexts leads to botanically different charcoal assemblages. Thus the difference in context between the Late Chalcolithic and Middle Bronze Age samples, which are likely to be hearth remains, and the mixed house debris from the Iron Age could be the reason for the lack of oak woodland charcoal in the Iron Age. However, this is unlikely, since a household context would usually contain a representative flora of most taxa near to the site due to the greater diversity of wood forms that are burnt. A house fire would include a mix of wood from building construction, furniture, tools, domestic objects, and firewood stores. Hearth remains primarily contain taxa that were intentionally gathered from nearby vegetation and burnt as firewood (Willcox 2002). A household context is likely to contain a wider range of woods selected for a variety of purposes and objects and thus is representative of the surrounding vegetation. Therefore the lack of taxa from the oak woodland in the Iron Age probably reflects a depletion of the trees from the plain that forced the inhabitants of Sos Höyük to travel further into the Karapazarı Mountains to collect wood.

The seed results from Sos Höyük also are indicative of woodland reduction (Table 2). In the Mid dle Bronze and Iron Age samples the presence of a diverse weed seed flora together with sheep faecal pellets may indicate the use of dung fuel as a wood supplement, similar to findings from modern and ancient Maylan in Iran (Miller and Smart 1984). Indeed, having examined a range of samples from throughout the Bronze Age, Mark Nesbitt (cited in Newton 2004) found that at Sos Höyük weed seeds only entered the charcoal record in the Middle Bronze Age and concluded that this was suggestive of the introduction of dung fuel. In modern Yiğittaşı, dung bricks (tezek) are still used in the earth stove (tando or) and as an occasional supplement to the coal and wood bought in Pasinler (Hopkins 2000). At Sos Höyük, the remains of dung fuel were found in the Late Bronze Age industrial sector preserved as a highly alkaline chocolate-brown layer and were probably incorporated as fuel supplement into a lime production pit (Sagona et al. 1997). Thus, as the oak woodland resources were coming under pressure in the Middle Bronze Age, dung fuel may have been used as a fuel supplement.

This pattern of woodland depletion is comparable to findings from Malyan in Iran, Aşvan in south eastern Anatolia and pollen cores from the region. During the Middle Bronze Age at Malyan, juniper was exhausted from the pistachio-almond-maple-juniper woodland and was replaced as fuel by oak from mountain slopes $10 \mathrm{kms}$ away (Miller 1985). At Aşvan, charcoal analysis revealed that riverine taxa were severely depleted over the Late Chalcolithic and Early Bronze Age following initial settlement along the river (Willcox 1974). Sometime after the Early Bronze Age and before the first century BC, deforestation of the oak woodland led to the cultivation of poplar and finally the importation of timber in the Medieval Period. In Central Anatolia, the oak woodland around Eski Acıgöl is seen to decline sharply in pollen records from the Bronze Age, as the pine increases (Roberts et al. 2001). This decline of oak woodland is confirmed by a pollen core from Lake Imera in the highlands of Eastern Georgia, climatically similar to the Pasinler Valley, where the Quercus pollen decreases as the Pinus pollen increases in the second millennium BC (Kvavadze and Connor 2005; Connor et al. n.d.). The same pattern is present in several cores from Lake Van in southeastern Anatolia where Quercus pollen starts decreasing after 4000 BP and 
Pinus pollen begins expanding (Wick et al. 2003:673; Zeist van and Woldring 1978:270). Deforestation in the highlands of eastern Turkey during the Late Bronze Age is apparent through increased sedimentation along the Euphrates River Valley, when land clearing and climate desiccation caused increased erosion (Kuzucuoğlu 2003).

\section{Human Impact}

Human impact, either direct, through tree felling and fires, or indirect, through animal grazing, is the probable cause of deforestation in the Pasinler Valley. At some point between the Middle Bronze and Iron Age at Sos Höyük, arboreal diversity decreased considerably. In the Late Bronze Age, the entire northern sector of the site was an industrial quarter, with signs of intensive bone processing for marrow extraction and a complex of pits for plaster manufacture (Sagona et al. 1998). In these pits limestone was burnt to produce lime plaster, used in antiquity for floors, bowls, statues and other artefacts (Sagona et al. 1997, Miller 1990a). Lime manufacture required high temperatures and much fuel, one ton of lime plaster requiring two tons of limestone and two tons of wood fuel for burning (Miller 1990a). Fresh wood or charcoal can be used to convert limestone into plaster. Charcoal has a higher calorific value but its production is very inefficient and requires sapling timber (Miller 1985). Work at Bronze Age Maylan and surrounds found that certain villages were centres of lime production that serviced the nearby villages that had no kiln (Miller 1990b). It could be that Sos Höyük was one such centre of lime manufacture for some of the villages in the Pasinler Valley in the Late Bronze Age. The quantities of fuel required for plaster production in combination with land clearing for agriculture and the usual wood procurement for hearths and housing may have placed excessive pressure on the vegetation of the Pasinler Valley and contributed to the decline of the oak woodland. In particular, oak has the characteristics necessary for good charcoal manufacture (Horne 1982). Selection of saplings for lime-making would have impinged on oak proliferation and over time reduced the extent of the oak woodland. The advent of iron working in the Pasinler Valley may also have affected the vegetation cover.

In tandem with wood fuel collection, livestock grazing may have diminished the plant resources of the Pasinler Valley. Sheep and goats were the most prevalent animals slaughtered in the Early Bronze and Iron Ages (Howell-Meurs 2001:90) and were probably the primary herd type throughout the occupation of Sos Höyük, just as they are today (Sagona et al. 1997). These animals graze on soft-leaved vegetation, and are noted to prefer oak (Riehl 1999). As flocks of sheep and goats range across the land they constantly graze, killing freshly germinated seedlings and defoliating saplings. Over time, this would prevent the growth of the new generations of trees and eventually stop regeneration of certain species. In Central Anatolia, most woodland remnants are found on isolated rock outcrops where they are protected from grazing (Woldring and Cappers 2001). Grazing promotes the proliferation of antiherbivorous taxa with protective spines and unpalatable leaves and selects against soft-leaved taxa. In the Pasinler Valley, Crataegus and Rosa shrubs, both bearing woody spines, are present, whereas unprotected trees are rare, located in marshes and sheltered mountain niches (Newton 2004). Furthermore, shepherds and graziers of north-eastern Anatolia often burn the subalpine meadows in the autumn to promote grass growth after winter (Connor et al. 2004). For the mesophilic open oak woodland, intensive grazing in the Pasinler Valley together with increased fuel procurement in the Late Bronze Age, may have led to its depletion.

\section{Climatic Aridity}

Overgrazing in the Late Bronze Age may itself have been a function of the increasing climatic aridity in this period. From the beginning of the Holocene, humidity increased in the Near East which, with the improved climatic conditions, enabled the oak woodlands to first expand along the Mediterranean coasts and then, after a 3000-year delay, expand in the montane interiors of Anatolia as found at Eski Acıgöl and Lake Van around 8200BP (Roberts et al. 2001; Wick et al. 2003). This climatic optimum was maintained through the Bronze Age until 4000 BP when humidity levels began to decrease, which lowered the water levels at Lake Van (Wick et al. 2003; Lemcke and Sturm 1997) and Eski Acıgöl (Roberts et al. 2001). At 
Lake Van the oak woodlands were depleted and the drought intolerant trees from Eski Acigöl were consi derably reduced (Roberts et al. 2001; Wick et al. 2003). Similarly in Eastern and Southern Georgia, rainfall and temperature kept increasing until $4500 \mathrm{BP}$, permitting oak forest expansion and the raising of the tree line before conditions began to deteriorate around 3500 BP (Kvavadze and Connor 2005). The Pasinler Valley in the second millennium BC, located between Lake Van and Georgia, was probably similarly affected, with the treeline lowering and decrease of oak woodland in an already marginal environment, leaving pine as the dominant tree by the Iron Age, as occurred at Lake Imera (Kvavadze and Connor 2005). At Lake Van (Wick et al. 2003) and Gravgaz in Southwest Anatolia (Vermoere et al. 2000) the oak woodland's decline is interpreted as a product of Holocene desiccation reducing the oak woodland's climatically favourable distribution. In contrast, at Eski Acıgöl after the loss of the drought intolerant species at the onset of the Holocene arid phase, the oak pollen has a delayed but marked fall which Roberts et al. (2001:733) interpreted as an anthropogenic change. Around Sos Höyük, as at Eski Acıgöl, the growing climatic aridity from the Middle Bronze Age onward, in tandem with human agricultural and settlement practices, may have led to the depletion of the open oak woodland.

Indeed over several years, increased summer aridity may have hastened the death of pasture plants early in the summer, leaving the flocks of goats and sheep to graze on the surrounding trees for the remainder of the season (Newton 2004). These trees, in the Late Bronze Age were already in decline due to decreased rains in the spring growing season (Wick et al. 2003). Today semi-nomadic herders from southern Turkey walk their flocks over the Taurus Mountains into Erzurum to graze on the Karapazar1 plateau for the summer months (personal observation). This is a tradition that may have occurred for thousands of years (A. Sagona personal communication). With increased aridity across the Near East during the Late Bronze Age, the amount of migratory herders travelling to the relatively rich pastures of the Pasinler Valley in summer may have increased. As a modern analogue, the influx of migratory cattle herds to Lake Victoria in Tanzania during a recent arid period caused substantial deforestation and promotion of cattle-tolerant species (Hongo and Masikini 2003).

Therefore, these preliminary findings suggests that the depletion of the open oak woodland in the Pasinler Valley was initiated by the onset of climatic aridity in the Middle Bronze Age and was exacerbated by human activities. It should be remembered that Sos Höyük is not the only known settlem ent in the valley. A survey of the Pasinler region located 22 Middle Bronze Age sites scattered across the valley floor and 45 Iron Age sites mainly in the foothills zone (NEAAP). By the time Xenophon marched through the Pasinler Valley in the fourth century BC the abundant woods he passed were probably composed primarily of pine and birch. The timing of the final deforestation of the Pasinler Valley which eliminated the pine and birch forests is uncertain.

A pollen record from north of Sos Höyük, dating back 700 years $(620 \pm 60 \mathrm{BP})$, indicates that since then the arboreal vegetation on the Karapazarı Mountain slope has been sparse, with only a few isolated pines and birches (Connor personal communication). To the south, on the northern slopes of the Palandöken Mountains, pine and birch may have been more common. Today, the mountain slopes are practically treeless. This final deforestation probably occurred in the last 500 years, when a sizable nomadic population of Eastern Anatolia settled to form village communities (McNeill 1992). Yiğittası, the village of Sos Höyük, may have been resettled at this time. At Van the oak woodland was cleared with in the last 600 years (Wick et al. 2003), coinciding with village proliferation. Indeed Erzurum recorded a two thousand-fold increase in population in the 16th Century AD (Jennings 1976). The effect of this population shift was seen by the French botanist Joseph Pitton de Tournefort in 1702. Travelling through Erzurum he commented on 'the scarcity and dearness of Wood. Nothing but Pine-wood is known there, and that too they fetch two or three days Journey from the Town; all the rest of the Country is quite naked.' (Tournefort 1718:194). As Tournefort passed through the Pasinler Valley he noted 'There is not a Tree to be seen in all this part of the Country, which otherwise is flat, well cultivated and water'd as abundantly as the Fields of Erzeron [Erzurum]' (Tournefort 1718:212). By the 18th century AD the forests of the Pasinler Valley were gone, perhaps felled only a few centuries before. 


\section{Conclusions}

From these preliminary findings, a picture of deforestation in the Pasinler Valley emerges from the macrobotanical remains of the Late Chalcolithic, Middle Bronze and Iron Ages. The modern alpine meadows of the Pasinler Valley are a cultural landscape, created by two distinct deforestation events. While this study was limited to only three loci, a number of initial observations can be made. In the Late Chalcolithic, initial occupants of the site gathered their wood from nearby in the riparian woodland, oak woodland on the plain and from the mountain pine forest. In the Middle Bronze Age the inhabitants were exploiting the full range of vegetation types hypothesised for the Pasinler Valley, collecting timber from the nearby riparian woodland, the open oak woodland and the pine and birch forests on the southern slopes of the Karapazarı Mountains. By the Iron Age only the riparian woodland and the mountain pine and birch forests were used for wood gathering. Representatives of the oak woodland on the plain were absent from the Iron Age sample. This suggests that sometime between the Middle Bronze and Iron Age the oak woodland was depleted which is in accordance with findings from Lake Van (Wick et al. 2003), Eski Acıgöl (Roberts et al. 2001), and Eastern Georgia (Kvavadze and Connor 2005). The use of dung fuel as a supplement for firewood may indicate that the deforestation of the Pasinler Valley was a gradual process beginning in the Middle Bronze Age. Increasing climatic aridity together with goat grazing, land clearing and intensified industrial activities in settlements may have contributed to the decline of the oak woodland in the late second millennium BC and caused the inhabitants of Sos Höyük to change their wood procurement strategies. The final deforestation of the Pasinler Valley, the felling of the pine and birch forests, occurred prior to $1700 \mathrm{AD}$ perhaps as a result of the settling of the nomadic population of Eastern Anatolia. This two-tiered deforestation model may be the pattern for vegetation change across the highland regions of the Near East. Due to the limited nature of this study further analysis of the charcoals from Sos Höyük is needed to confirm these trends and to help clarify the timing of these events. Future investigations into the archaeobotantical material of Sos Höyük and neighbouring sites may modify these initial conclusions.

\section{Acknowledgements}

Thanks to: Simon Connor and Andy Fairbairn for many discussions on the material from Sos Höyük; Michael Mackay from the Australian Winter Cereal Collection in Tamworth who sent seed samples to aid with analysis; Jenny Newton for initiating work on this project. 


\section{References}

Anderberg, A. 1994. Atlas of seeds and small fruits of northwest-European plant species with morphological descriptions Part 4. Stockholm: Swedish Museum of Natural History.

Asouti, E. and P. Austin. 2005. Reconstructing woodland vegetation and its exploitation by past societies, based on the analysis and interpretation of archaeological wood charcoal macro-remains. Environmental Archaeology 10(1):1-18.

Asouti, E. and J. Hather. 2001. Charcoal analysis and the reconstruction of ancient woodland vegetation in the Konya Basin, south-central Anatolia, Turkey: Results from the Neolithic site of Çatalhöyük East. Vegetation History and Archaeobotany 10:23-32.

Berggren, G. 1969. Atlas of seeds and small fruits of northwest-European plant species with morphological descriptions Part 2. Stockholm: Swedish Museum of Natural History.

Berggren, G. 1981. Atlas of seeds and small fruits of northwest-European plant species with morphological descriptions Part 3. Stockholm: Swedish Museum of Natural History.

Brazier, J. and G. Franklin. 1961. Identification of hardwoods - A microscope key. London: Her Majesty's Stationery Office.

Collins, P. E. F., D. J. Rust, M. Salih Bayraktutan and S. D. Turner. 2005. Fluvial stratigraphy and palaeoenvironments in the Pasinler Basin, eastern Turkey. Quaternary International 140-141: 121-134.

Connor, S. n.d. A Holocene palaeoenvironmental reconstruction of the South Caucasus. PhD thesis (in progress). Melbourne: School of Anthropology, Geography and Environmental Studies, The University of Melbourne.

Connor, S. E., C. Longford, J. Newton, and A. Sagona. n.d. A history of highland vegetation and prehistoric human activity in the Pasinler Valley, eastern Anatolia (in progress).

Connor, S. E., I. Thomas, E. V. Kvavadze, G. J. Arabuli, G. S. Avakov and A. Sagona. 2004. A survey of modern pollen and vegetation along an altitudinal transect in southern Georgia, Caucasus region. Review of Palaeobotany and Palynology 129:229-250.

Davis, P. (ed). 1965-1988. Flora of Turkey and East Aegean Islands Vols 1-9. Edinburgh: Edinburgh University Press.

Dönmez, E. 2003. Urartian crop plant remains from Patnos (Ağri) eastern Turkey. Anatolian Studies 53:89-95.

Dvorak, J., M.-C. Luo, Z.-L. Yang and H.-B. Zhang. 1998. The structure of Aegilops tauschii genepool and the evolution of hexaploid wheat. Theoretical Applied Genetics 97:657-670.

Ertuğ, F. 2000. An ethnobotanical study in Central Anatolia (Turkey). Economic Botany 54:155-182.

Fahn, A., E. Werker and P. Baas. 1986. Wood anatomy and identification of trees and shrubs from Israel and adjacent regions. Jerusalem: Israel Academy of Science and Humanities.

Fairbairn, A., E. Asouti, J. Near and D. Martinoli. 2002. Macro-botanical evidence for plant use at Neolithic Çatalhöyük, south-central Anatolia, Turkey. Vegetation History and Archaeobotany 11:41-54.

Frangipane, M., G. M. Di Nocera, A. Hauptmann, P. Morbidelli, A. Palmieri, L. Sadori, M. Schultz and T. Schmidt-Schultz. 2001. New symbols of a new power in a 'royal' tomb from 3,000 BC Arslantepe, Malatya (Turkey). Paléorient 27(2):105-139.

Greguss, P. 1955. Identification of living gymnosperms on the basis of xylotomy. Budapest: Akademiai Kiado.

Hongo, H. and M. Masikini. 2003. Impact of immigrant pastoral herds to fringing wet lands of Lake Victoria in Magu district, Mwanza region, Tanzania. Physics and Chemistry of the Earth 28:1001-1007.

Hopkins, L. 2000. The ethnoarchaeology of northeastern Turkey - Sos Höyük and Yiğittaşı village. Unpublished $\mathrm{PhD}$ thesis. Melbourne: School of Art History, Cinema, Classics and Archaeology, The University of Melbourne.

Horne, L. 1982. Fuel for the metal worker. Expedition 25:6-13.

Howell-Meurs, S. 2001. Early Bronze and Iron Age animal exploitation in northeastern Anatolia: The faunal remains from Sos Höyük and Büyüktepe Höyük. Oxford: Archaeopress. 
Jennings, R. 1976. Urban population in Anatolia in the sixteenth century: A study of Kayseri, Karaman, Amasya, Trabzon and Erzurum. International Journal of Middle Eastern Studies 7:21-57.

Kvavadze, E. V. and S. E. Connor. 2005. Zelkova carpinifolia (Pallas) K. Koch in Holocene sediments of Georgia - an indicator of climatic optima. Review of Palaeobotany and Palynology 133:69- 89.

Kuzucuoğlu, C. 2003. Environmental changes in southern (Antalya) and south-eastern (Euphrates Valley) Turkey, at the end of the 2nd Millenium BC and beginning of the 1st Millennium BC. In B. Fischer, H. Genz, E. Jean and K. Koroglu (eds), Identifying changes: The transition from Bronze Age to Iron Ages in Anatolia and its neighbouring regions, pp 271-281. Istanbul: Turk Eskicağ Bilimleri Enstitusu.

Lemcke, G. and M. Sturm. 1997. $\$ 180$ and trace element measurements as proxy for the reconstruction of climate changes at Lake Van (Turkey), preliminary results. In H. N. Dalfes, G. Kukla and H. Weiss (eds), Third Millennium BC climate change and Old World collapse. NATO ASI Series 1, 49:653-678.

McNeill, J. 1992. The mountains of the Mediterranean world. Cambridge: Cambridge University Press.

Miller, N. 1985. Paleoethnobotanical evidence for deforestation in ancient Iran: A case study of urban Malyan. Journal of Ethnobiology 5:1-19.

Miller, N. 1986. Vegetation and land use. In G. Algaze, K. Ataman, M. Ingraham, L. Marfoe, M. McDonald, N. Miller, C. Snow, G. Stein, B. Verharen, P. Wattenmaker, T. Wilkinson and A. Yener. The Chicago Euphrates archaeological project 1980-1984: Interim report. Anatolica 13:85-89/119-20.

Miller, N. 1990a. Archaeobotanical perspectives on the rural-urban connection. In N. Miller (ed.), Economy and Settlement in the Near East, pp 79-83. Philadelphia: MASCA.

Miller, N. 1990b. Clearing land for farmland and fuel: Archaeobotanical studies of the ancient Near East. In N. Miller (ed.), Economy and Settlement in the Near East, pp 71-77. Philadelphia: MASCA.

Miller, N. 1991. The Near East. In W. van Zeist, K. Wasylikowa and K.-E. Behre (eds), Progress in Old World Palaeoethnobotany, pp 133-160. Rotterdam: Balkema.

Miller, N. 1998. Patterns of agriculture and land use at Medieval Gritille. In S. Redford (ed.), The Archaeology of the Frontier in the Medieval Near East: Excavations at Gritille, Turkey, pp 211-252. Philadelphia: University Museum Publications.

Miller, N. 2004. Flotation samples from the 1992 excavation at Tell Jouweif. In T. J. Wilkinson (ed.), On the Margin of the Euphrates: Settlement and Land use at Tell es-Sweyhat and in the Upper Lake Assad Area, Syria, pp 157-165. Chicago: Oriental Institute Publication.

Miller, N. and T. Smart. 1984. Intentional burning of dung as fuel: A mechanism for the incorporation of charred seeds into the archaeological record. Journal of Ethnobiology 4:15-28.

Newton, J. 2004. Life in the mountains of Anatolia: A study of a Bronze Age settlement in its environmental context. Unpublished PhD thesis. Melbourne: School of Anthropology, Geography and Environmental Studies, The University of Melbourne.

NEAAP 1994-2002. North-East Anatolia Archaeological Project Archives, Melbourne.

Parr, E. M., C. Briggs and A. Sagona. 1999. Physical anthropological analysis of skeletons from Sos Höyük. Ancient Near Eastern Studies 36:150-68.

Pearsall, D. 2000. Paleoethnobotany. A handbook of procedures. San Diego: Academic Press.

Riehl, S. 1999. Bronze Age environment and economy in the Troad: The archaeobotany of Kumtepe and Troy. BioArchaeologica 2. Tubingen: Mo Vince Verlag.

Riehl, S. and M. Nesbitt. 2003. Crops and cultivation in Iron Age Near East: Change or continuity? In B. Fischer, H. Genz, E. Jean and K. Koroglu (eds.), Identifying changes: The transition from Bronze Age to Iron Ages in Anatolia and its neighbouring regions, pp 301-312. Istanbul: Turk Eskicağ Bilimleri Enstitusu.

Roberts, N., J. M. Reed, M. J. Leng, C. Kuzucuoğlu, M. Fontugne, J. Bertaux, H. Woldring, S. Bottema, S. Black, E. Hunt and M. Karabıyıkoğlu. 2001. The tempo of Holocene climatic change in the eastern Mediterranean region: New high-resolution crater-lake sediment data from central Turkey. The Holocene 11(6):721-736. 
Sagona, A. 2000. Sos Höyük and the Erzurum region in late prehistory: A provisional chronology for northeast Anatolia. In C. Marro and H. Hauptmann (eds), Chronologies des pays du Caucase et de l'Euphrate aux IVè-IIlè millénaires, pp 329-373. Paris: de Boccard.

Sagona, A., M. Erkmen, C. Sagona and I. Thomas. 1996. Excavations at Sos Höyük, 1995, second preliminary report. Anatolian Studies 46:27-52

Sagona, A., M. Erkmen, C. Sagona and S. Howells. 1997. Excavations at Sos Höyük, 1996, third preliminary report. Anatolica 23:181-226.

Sagona, A., M. Erkmen, C. Sagona and I. McNiven. 1998. Excavations at Sos Höyük, 1997, fourth preliminary report. Anatolica 24:31-64.

Sagona, A. and C. Sagona. 2000. Excavations at Sos Höyük, 1998 to 2000: Fifth preliminary report. Ancient Near Eastern Studies 37:56-127.

Sagona, A., C. Sagona and H. Ozkorucuklu. 1995. Excavations at Sos Höyük 1994 - First preliminary report. Anatolian Studies 45:193-218.

Sagona, C. 2004. Did Xenophon take the Aras Highroad? Observations on the historical geography of North-east Anatolia. In A. Sagona (ed.), A view from the Highlands, pp 299-333. Herent: Peeters.

Schoch, W., I. Heller, F. H. Schweingruber and F. Kienast. 2004. Wood anatomy of Central European species. URL: http://www.woodanatomy.ch

Stern, R. 1983. Human impact on tree borderlines. In W. Holzner, M. Werger and I. Ikusima (eds.), Man's impact on vegetation, pp 275-299. The Hague: Dr W. Junk Publishers.

Smart, T. and E. Hoffman. 1988. Environmental interpretation of archaeological charcoal. In C. Hastorf and V. Popper (eds), Current paleoethnobotany, pp 167-205. Chicago: University of Chicago Press.

Tournefort, J. P. de. 1718. A voyage into the Levant: Perform'd by command of the late French King, Vol 2, (trans. J. Ozell). London: D. Brown and Co.

van Zeist, W. and J. Bakker-Heeres. 1985. Archaeobotanical studies in the Levant. 1. Neolithic sites in the Damascus Basin: Aswad, Ghoraifé, Ramad. Palaeohistoria 24:165-256.

van Zeist, W. and J. Bakker-Heeres. 1986. Archaeobotanical studies in the Levant. 4. Bronze Age sites on the North Syrian Euphrates. Palaeohistoria 27:247-316.

van Zeist, W. and H. Woldring. 1978. A postglacial pollen diagram from Lake Van in east Anatolia. Review of Palaeobotany and Palynology 26:249-276.

Vermoere, M., E. Smets, M. Waelkens, H. Vanhaverbeke, I. Librecht, E. Paulissen and L. Vanhecke. 2000.

Late Holocene environmental change and the record of human impact at Gravgaz near Sagalossos, Southwest Turkey. Journal of Archaeological Science 27:571-595.

Wasylikowa, K., M. Carciumaru, E. Hajnalova, B. Hartyanyi, G. Pashkevich and Z. Yanushevich. 1991. East-Central Europe. In W. van Zeist, K. Wasylikowa and K.-E. Behre (eds), Progress in Old World palaeoethnobotany, pp 207-239. Rotterdam: Balkema.

Wick, L., G. Lemcke and M. Sturm. 2003. Evidence of late glacial and Holocene climatic change and human impact in eastern Anatolia: High-resolution pollen, charcoal, isotopic and geochemical records from the laminated sediments of Lake Van, Turkey. The Holocene 13(5):665- 675.

Willcox, G. 1974 A history of deforestation as indicated by charcoal analysis of four sites in Eastern Anatolia. Anatolian Studies 24:117-133.

Willcox, G. 2002. Evidence for ancient forest cover and deforestation from charcoal analysis of ten archaeological sites on the Euphrates. In S. Thiébault (ed.), Charcoal analysis: Methodological approaches, palaeoecological results and wood use, pp 141-145. Oxford: Archaeopress.

Woldring, H. and R. Cappers. 2001. The origin of the 'Wild Orchards' of Central Anatolia. Turkish Journal of Botany 25:1-9.

Xenophon. 1972. The Persian expedition, (trans. R. Warner). Aylesbury: Penguin Classics.

Zohary D. and M. Hopf. 2000. Domestication of plants in the Old World. Oxford: Oxford University Press

Zohary, M. 1973. The Geobotanical foundations of the Middle East, Vol 1-2. Amsterdam: Swets and Zeitlinger. 